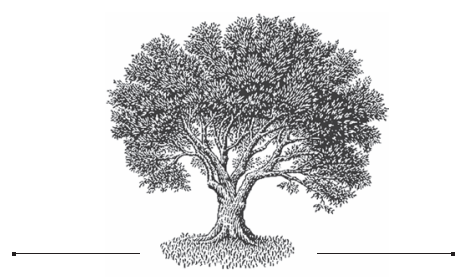

Книга Бытия

в Полной

хронографической

палее и Троицкие

Пятикнижия № 1

и № 45

\section{Татьяна Деонидовна Видкул}

Институт истории Украины

Национальной академии наук Украины

Киев, Украина

\title{
The Book of Genesis in the Complete Chronographic Palaea and the Trinity Pentateuchs No. 1 and No. 45
}

\section{Tatiana L. Vilkul}

Institute of History of Ukraine of Ukrainian National Academy of Sciences

Kiev, Ukraine

\section{Резюме}

Происхождению фрагментов древнеславянского четьего библейского перевода Х в. (т. е. 'предназначенного для домашнего и монастырского чтения') в Полной хронографической палее до сих пор уделялось не слишком много внимания. Основная цель данной статьи - определить использованную в Полной палее версию Книги Бытия на основе сравнения текстуальной традиции Восьмикнижия, Пятикнижия и хронографов. Как известно, Полная Хронографическая палея относится к древнерусским компиляциям, содержащим, с одной стороны, ветхозаветные тексты, с другой - хронографические источники. Ее библейская часть скомпонована из материала Тодковой палеи, а также фрагментов четьего библейского перевода, в хронографической же части помещены выдержки из византийских хроник в версии так называемого «Хронографа по великому изложению», с дополнениями. Рукописная традиция четьего перевода Восьмикнижия вкдючает три редакции текста, и заимствования из четьего Бытия в палее обнаруживают мало

Цитирование: Вилкул Т. А. Книга Бытия в Полной хронографической палее и Троицкие Пятикнижия № 1 и № 45 // Slověne. 2020. Vol. 9, № 2. C. 129-148.

Citation: Vilkul T. L. (2020) The Book of Genesis in the Complete Chronographic Palaea and the Trinity Pentateuchs No. 1 and No. 45. Slověne, Vol. 9, № 2, p. 129-148.

DOI: $10.31168 / 2305-6754.2020 .9 .2 .5$ 
сходства с двумя из них, а именно - Русской и Южнославянской редакциями. Зато множество сближений видим с группой Троицких Пятикнижий (РГБ ф. 304. I, № 1 и № 45). Текст этой группы принадлежит к третьей, Хронографической редакции четьего Бытия, характерные варианты охватывают десятки примеров тождественных инноваций. Вместе с тем некоторые расхождения с Троицкой группой и сближения с исходными чтениями из иных редакций показывают, что составитель Полной палеи имел дело с более ранним общим протографом. Хронографическая редакция разделииась на две группы, Троицкие Пятикнижия и Иудейский хронограф, по-видимому, в к. XII - нач. XIII вв., и ныне представлена дишь пятью списками. Соответственно, материал Полной палеи важен и для текстологического изучения древнеславянского Восьмикнижия, и для истории хронографии.

Ключевые слова

средневековая дитература, древнеславянские библейские переводы, церковнославянский язык, древнерусские хронографические компиляции

\section{Abstract}

Some parts of the Complete Chronographic Palaea contain fragments of an Old Slavonic translation of the Bible, which was intended for personal home or monastic reading (chetij in Old Slavonic). The origin of this translation has not received much scholarly attention so far. The main purpose of this paper is to identify the version of the Book of Genesis used in the Palaea by comparing the textual traditions of the Slavonic Pentateuch, Octateuch and chronographs. The Complete Chronographic Palaea is one of the Old Russian compilations containing both the Old Testament translations and chronographic sources. Its biblical part is built on the material of the Palaea Interpretata, as well as on the Slavonic "chetij" biblical translation, while the chronographic part has excerpts from the translated Byzantine chronicles after the version of the so-called Chronograph po velikomu izlozheniju with additions. Overall, the manuscript tradition of the Slavonic Octateuch includes three families. While interpolations from the Genesis in the Complete Palaea reveal little resemblance to two of them, namely, Russian and South Slavic recensions, we see dozens overlaps with the group of the Trinity Pentateuchs (Russian State Library, f.304. I, No.1 and No.45). The text of this group belongs to the third, Chronographic recension of the "chetij" Octateuch with specific features covering dozens of examples of identical innovations. However, some discrepancies with the Trinity Pentateuchs and convergence with the original readings preserved in two other recensions show that the compiler of the Complete Palaea was dealing with an earlier common protographe. The Chronographic recension itself was divided into two groups (Trinity Pentateuchs and Iudejsky Chronograph) approximately in the late 1100s or early 1200 s and is now represented by only five manuscripts. Therefore, the evidence of the Complete Chronographic Palaea is important both for the textual analysis of the Old Slavonic biblical translations and for the history of the Old Russian chronographs as well.

Keywords

medieval literature, Old Slavonic biblical translations, Old Church Slavonic, Old Russian chronicles 
В древнеславянских и древнерусских текстах встречается слово «палея», от греч. $\pi \alpha \lambda \alpha \imath \alpha$ 'древняя'. В терминологическом смысле в славистике оно обозначает компиляцию, в основу которой легли ветхозаветные тексты. Существуют четыре вида палей: Толковая, Полная и Краткая хронографические, и Историческая палея ${ }^{1}$. Начиная с Толковой палеи, библейская история излагалась в объеме от сотворения мира до Давида и Соломона, включая Восьмикнижие и первые две книги Царств. В Полной хронографической палее тексты Библии пополнены еще вставками из переводных византийских хроник. После окончания палейной половины, скомпонованной из Толковой палеи, фрагментов Восьмикнижия и парабиблейских источников, продолжаются хронографические выписки из так называемого «Хронографа по великому изложению». Изложение доведено до середины X в., подобно тому как это сделано в Хронике Георгия Амартола. Недавно был обнаружен пятый, переходный вид палеи - Барсовская. Она известна в единственном списке (ГИМ, собр. Барсова № 619), датируемом рубежом XIV-XV вв. или 2-й пол. XIV в. [Алексеев 1993; Водолазкин 2007: 20-22; Водолазкин 2009]. Барсовская палея представляет собою как бы «черновик» Полной хронографической палеи ${ }^{2}$.

Спор о том, что считать исходной компиляцией - Толковую или Полную Хронографическую палеи, - решен в пользу Толковой. Иследователю древнерусской исторической и хронографической переводной литературы В. М. Истрину еще в нач. XX в. удалось показать, что в Полной палее библейский текст двуслоен. Первый слой содержит отрывки из Толковой палеи с пересказом ветхозаветных книг с остатками толкований. Второй слой включает интересующие нас фрагменты, точно воспроизводящие полный или четий библейский перевод³. Однако

1 Поскольку в литературе иногда упоминаются синонимичные названия, идущие из дореволюционных трудов, имеет смысл дать краткую справку. Старое название Толковой палеи, унаследованное из XIX в., - Коломенская, оно дано по месту написания списка, городу Коломне. Текст издавался неоднократно, напр. [Палея Толковая 2002]. Рукопись оцифрована, см. РГБ, собр. Троице-Сергиевой Лавры, № 38, см.: https://lib-fond.ru/lib-rgb/304-i/f-304i-38 (далее ссылки на это собрание: https://lib-fond.ru/lib-rgb). Старое название Полной хронографической палеи - Синодальная, оно дано по названию собрания, в котором хранится рукопись (ГИМ, Синодальное собрание № 210). Текст частично опубликован [Толковая палея 1892]. Старое название Краткой хронографической палеи Палея Срезневского, современный шифр БАН, 24.5.8. Не менялось лишь название Исторической палеи, которая, в отличие от компиляций, сделанных древнерусскими составителями, является переводом на древнеславянский с греческого. Полезная библиографическая коллекция о палеях: [Orlov 2009].

2 Е. Г. Водолазкин обратил внимание на то, что на полях рукописи в разных местах текста остались значки, указывающие, как необходимо объединять фрагменты; и в самом деле, в Полной палее видим их синтез.

3 До сих пор не устарело исследование [Истрин 1907]. О дискуссии по поводу обеих палей с перечнем литературы [Словарь книжников 1987: 287-288]. 
до сих не было попыток определить версию вставок из четьего Восьмикнижия, которые были введены хронографическую компиляцию в $\mathrm{XIV}$ в.

Полный перевод первых восьми книг Библии, сохранившийся в сборниках Восьмикнижия и хронографов, а иногда Пятикнижия и его продолжений, был выполнен, по-видимому, болгарскими книжниками в начале X в. [см. напр.: Пичхадзе 1996]. Однако дошедшие до нас рукописи библейских сборников (ныне их известно около сотни) относятся к самому концу XIV-XVI ${ }^{4}$ вв. и более позднему времени. За этот длительный промежуток текст древнеславянского четьего перевода разошелся на три ветви-редакции, в свою очередь распавшиеся на группы списков. Редакции формировались в XII(?) -XIV вв. По моим наблюдениям, в древнерусских оригинальных сочинениях XI - начала XII вв. («Слово о законе и благодати», «Повесть временных лет», и др.), где имеются вставки из четьего Восьмикнижия, еще не прослеживается следов ни одной из перечисленных выше текстуальных ветвей, зато по этим памятникам в ряде случаев можно вычленить исходный текст. Имеются косвенные показатели более позднего, чем 1-я пол. XII в., формирования редакций Восьмикнижия. Напр., Южнославянская редакция содержит вставки из Исторической палеи, перевод которой, вероятно, сделан в XIII в. ${ }^{5}$ Одно из ответвлений восточнославянской Хронографической редакции - Иудейский хронограф - в части, содержащей Книги Бытия, Хронику Иоанна Малалы и др. компоненты, имеет дату составления, ведущую ко 2-й пол. XIII в.

История текста древнеславянской Библии, несмотря на несколько сотен лет изучения, по-прежнему нуждается в уточнениях. В частности, нет исчерпывающих сведений о трансмиссии рукописей библейских сборников, поэтому любые усилия в этом направлении важны. В Полной палее точно скопирована приблизительно четверть четьего Бытия, благодаря чему она предоставляет новые ценные данные. Ее версия близка как раз тому ответвлению рукописной традиции, которое хуже всего представлено в сохранившихся списках четьих библейских книг, а это представляет особую научную ценность.

Три редакции, образовавшиеся в результате трансмиссии первоначального перевода полного Восьмикнижия, следующие: Хронографическая, Русская и Южнославянская (далее: $\mathrm{Chr}, \mathrm{RU}, \mathrm{SO})$. Сохранилось около 60 кодексов, содержащих Книгу Бытия [Славова 2018: 97-99]. Пять из

4 При этом списков XIV в. очень немного: РГБ Троицкий № 1 (Пятикнижие), Троицкий № 2 (сборник с Книгой Иисуса Навина и др. книгами), Троицкий № 728 (старший список Троицкого хронографа). Все три оцифрованы, см. Главное собр. библиотеки Троице-Сергиевой Лавры: https://lib-fond.ru/lib-rgb.

5 Подробнее литературу и рассмотрение вопроса см.: [Reinhart 2007; Славова 2015]. 
них принадлежат Хронографической редакции ${ }^{6}$, около десятка приходится на Южнославянскую, Русская же представлена наибольшим числом рукописей. Редакции подразделяются на группы и подгруппы. Хронографическая редакция - на группы Троицких Пятикнижий (№ 1 и № 45, сиглы T1, T45) и Иудейского хронографа (списки Архивский, Виленский, Варшавский, сиглы Аpx, Вил, Варш). Русская редакция распадается на три группы: раннюю (RU-E), к которой принадлежат лишь три списка, в том числе Троицкий № 44 (T44), позднюю (RU-L) и позднюю с еврейскими глоссами (RUли общий протограф. Отдельно следует выделить подгруппу, в которую входит список из собрания Румянцева № 27 (P1). Протограф этой подгруппы принадлежал к RU-L, но, по моим наблюдениям, сверялся по какому-то списку, близкому к $T 1, T 45^{7}$. Южнославянская редакция состоит из двух групп, сербской (SO- $\left.{ }_{\text {SERB }}\right)$ и болгарской $\left(\mathrm{SO}-{ }_{\text {BULG }}\right)$. Ниже в разночтениях используются обозначения всех названных групп.

Данная статья продолжает работу, начатую подготовкой к публикации древнеславянской Книги Бытия по спискам XIV-XVI вв., проделанную автором совместно с С. Л. Николаевым ${ }^{8}$. Четий текст сравнивался по сборникам Восьмикнижия, Пятикнижия и хронографов. В нашем издании использован материал 18 списков, за основной избрано Троицкое Пятикнижие № 44 Русской редакции. Привлекались также издания и списки Паримейника (сборника чтений из Ветхого Завета, предназначенного для церковных служб) [Брандт 1894а; 1894б; 1900; 1901; Григоровичев Паримејник 1998], поскольку все славянские рукописи имеют паримейные вставки, хотя и отличающиеся по составу. В сложных узлах разночтений подведен греческий текст по критическому Геттингенскому изданию Септуагинты [Septuaginta 1974]. Во всех приведенных ниже примерах библейский материал взят из подготовленного издания, где в критическом аппарате обозначены листы рукописей (соответственно, номера листов из библейских сборников и хронографов не отмечаются). Сопоставление с Полной палеей проводится по спискам Погодинский № 1435 (П2), Синодальный № 210 (Сuн),

6 Ранее были известны только два, и их относили к «Промежуточной группе», но как оказалось, эта ветвь имеет статус отдельной редакции [Вилкул 2015].

7 В Восьмикнижиях, Пятикнижиях и др. библ. сборниках этой подгруппы имеются десятки общих чтений. Согласно Михайлову, к ней относятся списки: Румянцевский № 27 (РГБ, ф. 256), Кирилло-Белозерский № 3/8 (РНБ), и рукопись из Антониево-Сийского монастыря № 179 (современное место хранения которой установить не удалось). См.: [Михайлов 1912: XX-XXIV].

8 [Вілкул, Ніколаєв 2020]. Читатели также могут обратиться к предыдущему изданию Бытия [Михайлов 1900-1908]; в нашей публикации добавлены списки Троицкий № 45 и № 44, Варшавский, Виленский, сопоставление с греч. текстом и словоуказатели. 
при расхождениях названных двух привлекался также Румянцевский № $453(P \mathcal{M})$. Два из них оцифрованы ${ }^{9}$, что облегчает доступ и перепроверку чтений.

В Полной хронографической палее во фрагментах Бытия не прослеживается заимствований из Русской редакции, что показательно, учитывая широкую распространенность последней. B RU довольно много случаев, когда опущены слова, выражения и целые стихи (иногда в результате гаплографии, но не обязательно). Эти пропуски зачастую не мешают восприятию текста, так как приходятся на риторическое удвоение отдельных оборотов или же так называемые библейские повторы. Подобных сокращений не наблюдается в двух других редакциях и греческом оригинале, а также - что примечательно - в Полной палее. Примеров этому множество. Приведем несколько характерных (далее для восприятия чтений использованы графические маркеры: полужирным стилем выделены отличающиеся фрагменты в библейском тексте по разным версиям).

1. При перечислении царей, Быт 14:8, в RU отсутствуют 2 слова «[и цр̈ь севоимскы]»: текст, заключенный в квадратные скобки и выделенный полужирным шрифтом, приведен по двум другим редакци-

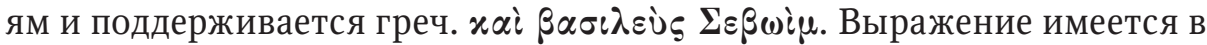
Полной палее, ср. Пг л. 72r с небольшой порчей «семоимьскь», Син л. 75а «семоискь».

2. В Быт 23:6 RU имеется гаплография в выражении «слоушаи насъ

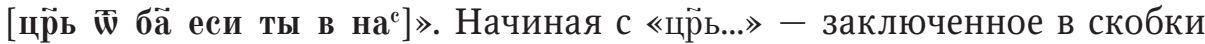
представляет собою пропуск, однако текст сохранен в Chr SO и Полной

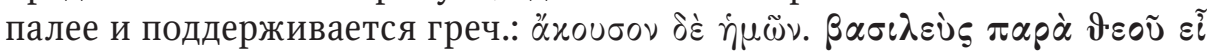

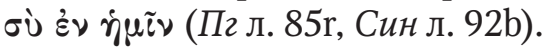

3. В Быт 32:19 «[и заповьда старъишему • второму • и третьяму • и]

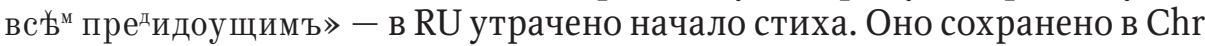
SO P1-подгруппе и Полной палее (Пг л. 97v, Син л. 109a) и соответствует

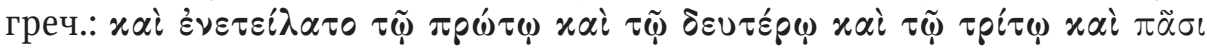

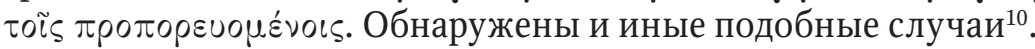

9 Синодальный № 210 cм.: https://catalog.shm.ru/entity/OBJECT/164750?album=6 22494765\&index=52. Румянцевский: ОР РГБ, ф. 256, собр. Румянцева, № 453, см.: https://lib-fond.ru/lib-rgb/256/f-256-453.

10 В Быт 15:19 воспроизведены два названия из опущенного в RU перечня племен (Пг л. 76r, Син л. 80d); полностью воспроизведено Быт 23:15, где в RU в этом месте пропуск (Пг 85v, Син 92c); то же касается Быт 24:7 (Пг л. 86r, Син л. 93b); в Быт 33:9 присутствует пропущенная в RU речь Исава в начале этого стиха (Пг л. 98r, Сuн л. 110a); палея не отражает гаплографию RU в Быт 38:17 (Пг л. 104v, Син л. 117d), нет пропуска в иных стихах. Ср. Быт 39:23 (Пг л. 108r, Син л. 121a), Быт 43:4 (Пг л. 112v, Син л. 126с), Быт 43:32 (Пг л. 114r, Син л. 128а), Быт 44:34 (Пг л. 115v, Син л. 130b), Быт 46:18 (Пг л. 120r, Син л. 135b). 
Палея также не имеет дополнений, присущих Русской редакции. Напр., в Быт 24:14 Авраамов раб едет к родственникам своего господина с поручением сосватать жену для его сына, Исаака. RU передает якобы раздумья раба: «(воды .) помыслихъ въ оумъ си и р'ъхъ . да боудеть дв̈ца». Выделенных слов нет в Chr SO и палее (Пг л. 86r, Сuн л. 93c),

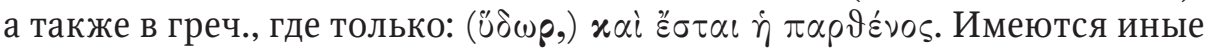
аналогичные разночтения (напр., Быт 33:10, Пг л. 98r, Син л. 110a). Не обнаруживается в палее и инноваций в именах и географических названиях, характерных для RU. Список таких «отрицательных» примеров настолько объемен, что совершенно невероятно предположение, что составитель Полной палеи мог бы опираться в своей компиляции на какую-нибудь рукопись Русской редакции. Сближения прослеживаются лишь в отдельных чтениях группы RUсложно решить - не могли ли они быть введены, наоборот, в эту ветвь из чтений палеи ${ }^{11}$.

С Южнославянской редакцией Полную палею сближают лишь отдельные общие ошибочные чтения. Их наличие объясняется, видимо, независимыми одинаковыми правками у разных писцов, ведь небольшой процент независимых близких и тождественных инноваций обычен для многих рукописей и повышается при высокой концентрации топики в памятниках. В данном случае подобные примеры к тому же не слишком выразительны. Укажем некоторые из них.

1. Быт 17:13, завет Господа Аврааму «да шбрбжет са домачАдець домоу твоєго и коупленыи . и боудеть завътъ мои на плъти вашеи» - в SO и Полной палее «да не шбрьжет сА» (Пг л. 77r, Син л. 81d). Греч. тєрєтой

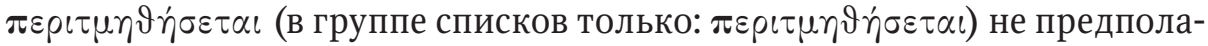
гает частицы «не». Однако в 17-й главе Бытия несколько раз повторено повеление «да шбръжет сА» по отношению к разным категориям людей (Быт 17:10-13), поэтому писцы могли недопонять, что речь идет еще об одном повторении, и заложить, так сказать, отрицательный казус. В Быт 37:35 видим одинаковое дополнение в SOмое, однако, к топике: Иаков оплакивает любимого сына Иосифа при

11 Подобные чтения есть в т. ч. в рукописи Иосифо-Волоцкого монастыря, № 8 , ОР РГБ, ф. 113 (сигл Михайлова В1), см.: https://lib-fond.ru/lib-rgb/113/f-113-8. Важных вариантов, строго говоря, два. В Быт 23:6 хеттеи предлагают Аврааму

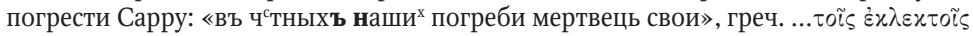
$\mu \nu \eta \mu \varepsilon i o \iota s \hat{\eta} \mu \tilde{\nu} \nu .$. Упоминание гробниц утерялось в славянском в большинстве списков, что видимо, восходит к проторграфу четьего перевода. B RU-

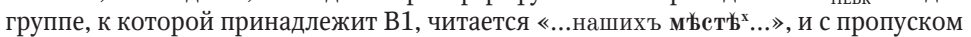
«нашихъ» такое же прибавление и в Полной палее: «въ ч тны $^{\mathrm{x}}$ м'ъете $^{\mathrm{x}}$ погреби...»

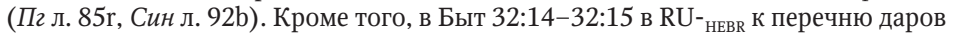
брату Исаву от стад Иакова (столько-то «козель, швенъ, быкъ, шселъ» и т. д.) добавлено еще «коровъ 40». В Полной палее в стихе 32:14 «кравъ .Ё. .й.» (Пг л. 97r; .̌̆. (20) на поле, Син л. 108d). 
ложном известии о смерти того «много дней». В большинстве списков в окончании стиха лишь «Плака сА $[\mathrm{Chr}+$ єго] шц̈ ь єго» - Ho SO«Плака же се оц̆ь его дйы многыи»; близко Пг Син «Плака сА его дйи мно-

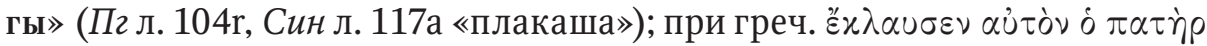

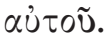

2. В Быт 41:34 Иосиф советует фараону в преддверии страшного семилетнего голода сотворить большие житницы, поставить старейшин землям и собрать в житницы пятую часть выращенного в период изобилия зерна: «и дасть (в большой группе списков: да) плтоую чАсть

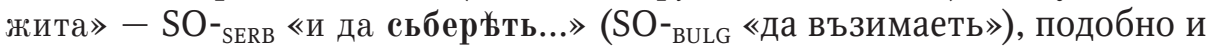
в Полной палее, «и да сбер8ть» (Пг л. 110r, Син л. 123b). Греч. иначе: х $\alpha і$ $\dot{\alpha} \pi 0 \pi \varepsilon \mu \pi \tau \omega \sigma \alpha \dot{\alpha} \omega \sigma \alpha \nu \pi \dot{\alpha} \nu \tau \alpha \tau \dot{\alpha} \gamma \varepsilon \nu \eta \dot{\mu} \mu \alpha \alpha$.

Гораздо более однозначны схождения с Хронографической редакцией. С ней сближают и вторичные чтения, и ряд исходных, сохраненных только в Chr и отсутствующих в двух других редакциях. Начнем с первых, так как сами по себе общие исходные чтения непоказательны и приобретают значение только в паре с надежными вторичными.

1. Так, в Быт 12:6 в RU «и шбыиде авраамъ землю всю», в SO T1 паримейная замена «пріиде», - в оставшихся списках Chr «и шбиходи...»,

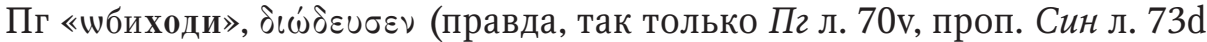
и Рм л. 55b).

2. В Быт 13:11 в Chr и Пг отсутствует слово «шба» в выражении

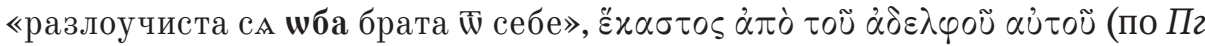
л. 71v, проп. выражения в Син л. 74d и Рм л. 56a).

3. В Быт 19:11 ангелы избавляют Лота от содомлян, избивая нападающих: «моужа же соущага пред дверми побиста не видимо». Ho Chr и

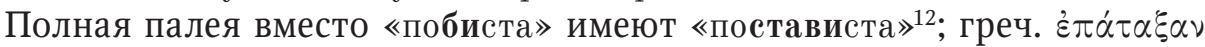
(Пг л. 79v, Син л. 85b).

4. Быт 21:23 в большинстве списков речи царя Авимелеха к Аврааму представлены в таком виде: «(по правдњ) юже сътворихъ. с тобою сътво-

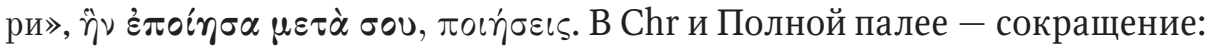
«юже сътвориши» (T1, T45, Син мелкая погрешность єже; Пг л. 82v, Сuн л. 89b). Одна из топографических отметок, «оу кладАзА видњннаго»,

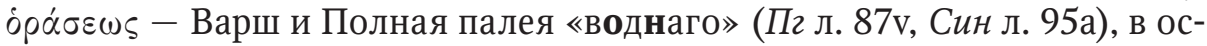
тальных списках Chr «виднаго», что легко трансформировалось в «водныи». В Быт 25:3 перечисление сыновей, среди которых по SO «и лоw-

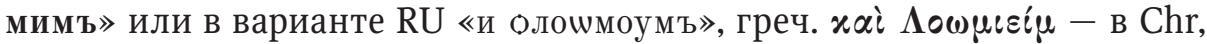
Полной палее пропуск имени (Пг л. 87v, Сuн л. 95b). Согласно Быт 37:3, Иаков очень любил первого сына от Рахили Иосифа: «сӥъ старостенъ ємоу бъ . сътвори же ємоу ризоу красноу», что точно соответствует греч.

12 Пг Син с дальнейшей инновацией: постависта невидъніемь. 


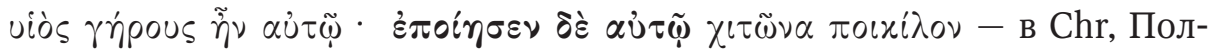
ной палее выделенные слова опущены, при этом еще в Т1 T45 и палее пропуск компенсирован заменой в конце фразы: «ризу красну носА» (Пг л. 102r, Син л. 114c). Быт 41:28 Иосиф рассуждает, что он изрек слово

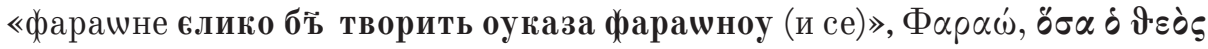

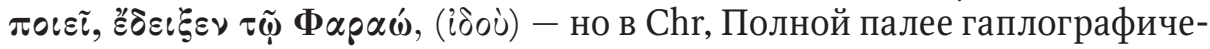
ский пропуск (Пг л. 110r, Син л. 123a). В Быт 43:30 видим сложный узел чтений, где описываются чувства Иосифа, увидевшего своего брата Вениамина после долгой разлуки: «рыдаше оутроба єго брата ра ${ }^{\text {д }}$ своєго». Полная палея поддерживает чтения $\mathrm{Chr}$ «вығше сх утроба» (так Вил, Т45 «выгше...», Арх Варш «быгше сл» ${ }^{13}$, ср. Пг л. 114r, Син л. 128a), тогда

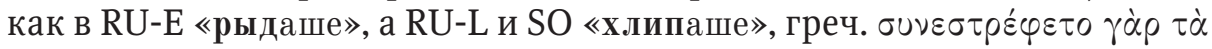
हैv $\varepsilon \rho \alpha$. Следует отметить: характерные чтения не захватывают крупных участков текста, но таково свойство Chr, где отклонения, объясняемые небольшими ошибками прочтения или диктовки, составляют большинство.

Примечательны и общие исходные чтения, сохраненные именно в Chr и палее.

1. Напр., в Быт 14:10 сообщается, что некое ‘соленое’ ущелье («алукигљ) имело необычные колодцы, в которые при бегстве свалились несколько царей. B RU и SO записано неверно: «юдоль же аликіа . имоущь кладАзь съверенъ». Нo Chr и Полная палея представляют другое чтение «оудоль же алукиг имАща кладазь [им8ща кладАзА] съры». Последнее, видимо, корректно передает оригинал, по крайней мере, в греч. о сторонах света

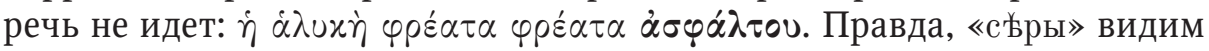
из палейных лишь в Погодинском списке, в Синодальном легкая порча: «кладаsь селы», аналогично в Румянцевском «кладазь силы» (Пг л. 72r, Син л. 75a, Рм л. 56b). Возможно, исходной формой было «сърьны (сърьнъ)», откуда легко возникала ошибка «съверенъ».

2. В Быт 24:32 в RU «и дасть пльвы и е'ьно велбоудомъ», однако Chr и Полная палея сохраняют лексему «поудъ» (Пг л. 86v, Син л. 94a), тогда как в SOэтом выше «поудъ» встречается еще в 24:25, где сохранено уже в рукописях двух ветвей - RU и T1, T45, причем в Арх Варш Вил порча «под», $\mathrm{SO}$ же «подногы», т. е. инновации образовалась именно из «поудъ» или «поудо» ${ }^{14}$. В Быт 42:24 иное выражение точно сохранено снова-таки в

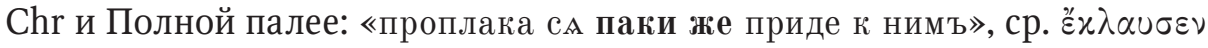

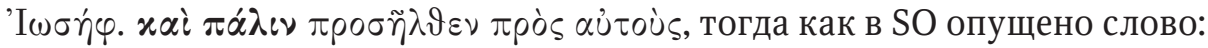
«проплакав се . пріиде кь ним», а в RU проп., и от всего выражения оста-

13 T1 иначе, паримейная замена «смущаше же сА».

14 SO «подногы» из двух слов в выражении: «поудъ мъного». 
лось лишь «проплакав сА» (Пг л. 112r, Син л. 125c). Аналогично в $\mathrm{Chr}$ Пг из Быт 44:23 сохранено слово «въщща» ${ }^{15}$, sĩ $\alpha \varsigma$, тогда как в остальных ветвях «шів вщща».

Таким образом, из трех редакций именно Хронографическая показывает ряд сближений с Полной хронографической палеей. Мы можем еще сузить поиски, поскольку в большом ряде чтений прослеживаются варианты палеи, тождественные инновациям одной из групп этой редакции, а именно, группе Троицких Пятикнижий.

Так, в Быт 12:8 в рассказе об Аврааме в целом корректно переданы топонимы, которые патриарх встречал по пути, ведомый наказами Господа. Из незначительных вариаций: Вефиль в T1, T45 пишется через «ф» «вефиль» (T1 с перестановкой букв: вифель), в RU-E переделано в «летиль», поздние ветви RU - дальнейшая порча «лиць», Аpx, Bapw, Вил SO «ветиль». При этом греч. В $\alpha \imath \hat{\eta} \lambda$ упомянут дважды, но в T1, T45 и Полной палее место соответствует второму, все остальные списки первому упоминанию ${ }^{16}$. Главное же, в Троицких Пятикнижиях и Полной палее почти корректно сохранено геогр. «Агге», перевод 'А $\gamma \gamma \alpha i$. Почти корректно, поскольку в T1 и палее удвоен предлог «Къ» (=x $\alpha \tau \dot{\alpha})$, т. е. читается «къ . ко» или «къ кь», первое «къ» присоединилось к названию, в результате чего получился «аггекъ» ${ }^{17}$. По-видимому, такую же ошибку содержал и антиграф T45, но переписчик этимологизировал ее в 'ангел': «аг̈ге"». Только в RU-E соответствующее название сохранено с порчей «и ате», в остальных же рукописях оно вообще пропущено. Таким образом, имеем одновременно яркий начальный вариант и незначительный вторичный в одном и том же узле разночтений, ср. табл. 1.

Среди чтений списков самой палеи более близкие к исходным дает Погодинский, а Синодальный и Румянцевский имеют общие инновации «хлевиноу» вместо «коущоу» и ошибки «февиль» вместо «вефиль» (выше в некоторых других примерах также видно, что два последних списка сближаются). Добавим, название «Агге» присутствует еще в Быт 13:3: оно сохранено в RU корректно, T45 дает вариант «агге ${ }^{\text {»», } T 1 ~-~}$ «ааггъємъ», в списках же Полной палеи здесь вновь «аггекъ» (Пг л. 71v, Син л. 74с, РМ л. 55d).

\footnotetext{
15 Ср. те стихи Книги Бытия, где слово сохранено в Т44 по словоуказателю, подготовленному С. Л. Николаевым: «въща» 20:5, 32:20, 37:19, 42:4, 42:21; «въ̌щати» 20:4. Надо сказать, в Полной палее «въщща» лишь по Пг л. 115v, тогда как Син л. 129с и Рм л. 102с тоже «шівьща».

16 Не исключено, разнообразные сокращения были связаны с тем, что писцы протографов редакций и групп старались устранить дубль названия, т. е. несмотря на схожесть, механизмы урезания цитаты были разными.

17 K T1, T45 здесь примыкают еще рукописи RU P1-подгруппы.
} 
Таблица 1

\begin{tabular}{|c|c|c|c|c|c|c|}
\hline $\begin{array}{l}\text { Пг л. } 70 \mathrm{v}, \\
\text { Син л. } 73 \mathrm{~d}, \\
Р_{\mathcal{M}} \text { л. } 55 \mathrm{~b}\end{array}$ & $T 1$ & T45 & RU & $\begin{array}{l}\text { Вил, Арx, } \\
\text { Варш }\end{array}$ & SO & $\begin{array}{l}\text { [Septu- } \\
\text { aginta, 1: } \\
151]\end{array}$ \\
\hline 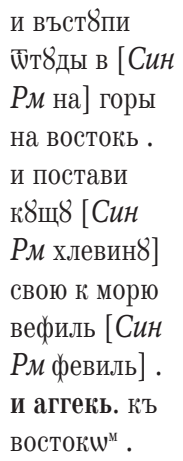 & $\begin{array}{l}\text { i wттьступи } \\
\text { шттуду в } \\
\text { горъ на } \\
\text { въстокы } \\
\text { поставі } \\
\text { кущу свою } \\
\text { к морю } \\
\text { вифель и } \\
\text { аггекъ ко } \\
\text { въстоку. }\end{array}$ & 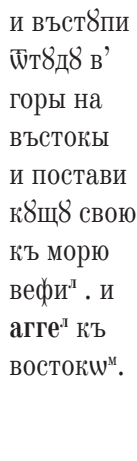 & $\begin{array}{l}\text { и въстоупи } \\
\text { шттоудоу } \\
\text { въ гороу } \\
\text { на въстокъ } \\
\text { летиль } \\
{[\text { лиць }]^{18} \cdot} \\
\text { и постави } \\
\text { храмъ свои } \\
\text { къ морю } \\
\text { и ате къъ } \\
\text { въстокш". }\end{array}$ & $\begin{array}{l}\text { и въст8пи } \\
\text { штт8доу въ } \\
\text { гор8, на } \\
\text { въстокы въ } \\
\text { ветиль , и } \\
\text { постави }{ }^{\circ} \\
\text { кущю свою } \\
\text { къ морю } \\
\text { и - - къ } \\
\text { востоко", }\end{array}$ & $\begin{array}{l}\text { и въст8пи } \\
\text { w̄тоуд8 въ } \\
\text { гороу на } \\
\text { вьстокь въ } \\
\text { ветилъ (въ } \\
\text { етиль) })^{19} . \\
\text { и постави } \\
\text { т8 коущоу } \\
\text { [SO- } \\
\text { хыжы }] \\
\text { свою къ } \\
\text { мор8 - -. }\end{array}$ & 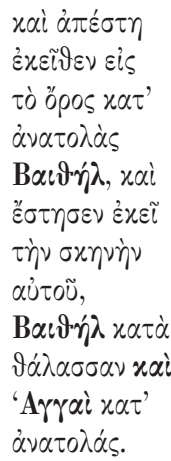 \\
\hline
\end{tabular}

В ином сложном узле разночтений, в сцене из Быт 42:23, когда братья Иосифа не поняли, что Иосиф, уже в роли знатного египетского вельможи, понимает их речь, поскольку между ними стоял переводчик, списки сильно разошлись. В исходном варианте видимо было «тлъка», однако видим также «толика», «толмача», «глаголь» и «гълка» (т. е. 'мятеж’). Последнее характерно как раз для T1, T45 и Полной палеи, правда, только в раннем варианте Погодинского списка (в двух других - замена на «молва»).

Таблицуа 2

\begin{tabular}{|c|c|c|c|c|c|}
\hline 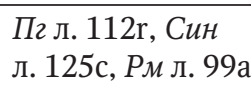 & $T 45+T 1$ & RU & $\begin{array}{l}\text { Арx, Варu, } \\
\text { Вил }\end{array}$ & SO- ${ }_{\text {SERB }}$ & $\begin{array}{l}\text { [Septuagin- } \\
\text { ta, 1: 400] }\end{array}$ \\
\hline 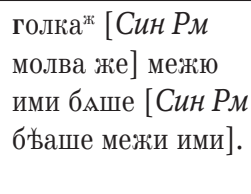 & $\begin{array}{l}\text { гълка [T1 } \\
\text { голка] же } \\
\text { меж8 ими } \\
\text { [T1 - -] бАше }\end{array}$ & $\begin{array}{l}\text { толика [др. } \\
\text { списки RU: } \\
\text { то»ка] бо не } \\
\text { бњше межоу } \\
\text { ими . }\end{array}$ & $\begin{array}{l}\text { толика [Bил } \\
\text { то"мача] бо } \\
\text { меж8 ими } \\
\text { не бъгғше }\end{array}$ & $\begin{array}{l}\text { гл̈ь бо } \\
\text { меж } 8 \text { ими } \\
\text { бъше }\end{array}$ & 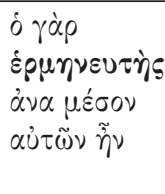 \\
\hline
\end{tabular}

Многочисленны и аналогичны, но не затрагивают сложные узлы разночтений случаи, когда Полная палея следует за T1, T45. См. Быт 19:2: большинство рукописей в ответе ангелов Лоту содержат утверждение, что те переночуют в Содоме «на стегнахъ» (ни оубо . на стегнахъ

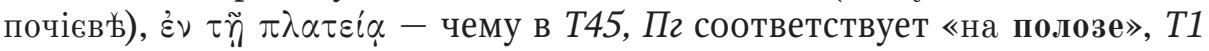

\footnotetext{
18 В списках RU-L варианты: льътен;

19 SO- BULG $_{\text {и два списка SO- }}^{\text {SERB }}$ въ етиль.

20 B SO- ${ }_{\text {вuLG }}$ инновация: «гїь иже бесъдоваахж междоу собож».
} 
«на поль» (только по Пг л. 79r; Син л. 84d и Рм л. 63d - пропуск выражения). В Быт 20:2 содомляне по Восьмикнижию названы «моужи град-

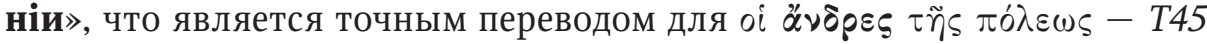
и Полная палея «гражане [Сuн гражани] града того», T1 сокращено до: «гражани» (Пг л. 81r, Син л. 87a). В Быт 24:36 раб рассказывает о своем господине Аврааме: «роди сарра... сйа... г ноу моємоу състаржвшоу сA $»^{21}$ - однако в T1, T45, Полной палее здесь иначе: «(моєму) сӥа на ста-

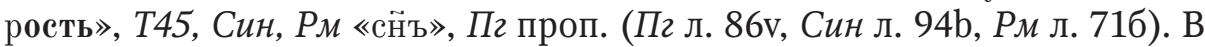
Быт 25:3 дается генеалогия Авраамовых детей от Хеттуры, модифицировано имя сына Дедана: «рагоуиль [и надаиль]»"2 , 'Р $\alpha \gamma$ о

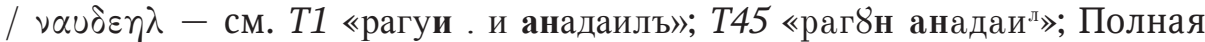
палея «раг8на . надаиль» (Пг л. 87v, Син л. 95b). Возможно, чтение объясняется палеографически: $л$ в рагоуил было передано как $a$, а $u$ как $н$. В Быт 32:12 в сетовании Иакова Господу говорится, что тот обещал, что племя его будет «ाко пьсокъ морскыи . иже сА не изчтеть», в T1, T45 и Полной палее выражение изменено по библ. формуле «...пъсокъ въскраи морА...» (Пг л. 97r, Син л. 108d).

Далее, согласно Быт 37:27, захватив Иосифа, братья вначале задумывали его убить, но затем передумали и решили продать купцам в Египет. О причине такого решения в большинстве списков читаем: «роуць наши да не боудета на не ${ }^{\mathrm{M}}$ гако бра ${ }^{\mathrm{T}}$ нашь и пльть наша єсть»,

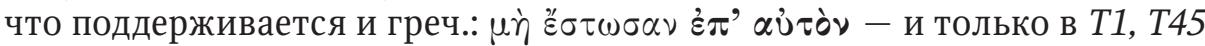
и Полной палее замена: «...не будета осквернен'ъ / шскве ${ }^{\mathrm{p}} \mathrm{нени...»} \mathrm{(Пг}$ л. 102v, Син л. 115b);

В Быт 38:5 имеются вариации в географических названиях. О месте, где пребывал Иуда, когда у него родился третий сын, сказано: «сіи же бъша [2 редакции против одной: бъгшше] въ хазви єгда роди сіг», что точно отражает греч. Х $\alpha \sigma \beta \ell$, чему в T1, T45 Полной палее соответствует «хазивъ» (Пг л. 104r, Син л. 117b). Согласно Быт 39:21, Иосифа бросили в Египте в темницу, в большинстве рукописей Восьмикнижия Господь дает «блг и стражемъ»; Полная палея «...цримь стражемь» (Пг л. 108r, Син л. $120 \mathrm{~d})^{23}$.

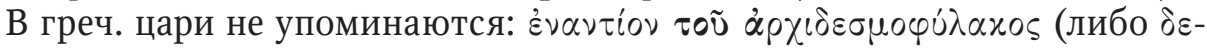
$\sigma \mu о \varphi$.).

В Быт 41:5 египетский фараон «видъ сънъ вторыи» - чему соответствует по Т1 Т45 и Полной палее «...друг ${ }^{\text {и }}$ / др8гыи» (Пг л. 109r, Син л. 122a). В Быт 43:6 Иаков упрекает своих сыновей, зачем поведали египетскому господину, не узнанному братьями Иосифу, «кко єсть ны

\footnotetext{
21 Греч. здесь не показателен: $\mu \varepsilon \tau \dot{\alpha}$.

22 RU проп. имя вместе с союзом «и», так Аpx, Варш, Вил, SO инновация: и данаиль.

23 Син исправлено на: црер $\mathrm{e}^{\mathrm{B}} \mathrm{M}$.
} 


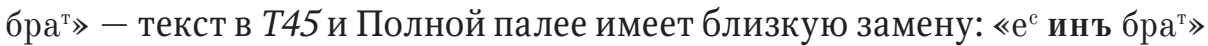

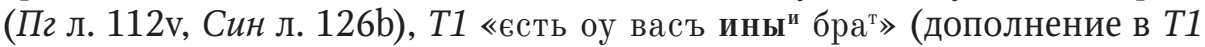
«оу васъ», видимо, сделано по контексту). Согласно греч., перевести

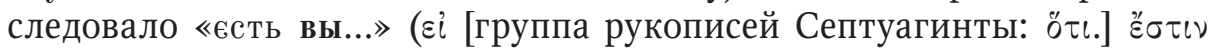

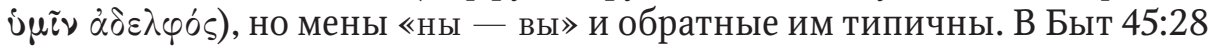
Иаков одобрительно комментирует известие о том, что его любимый сын Иосиф стал египетским вельможей, получив предложение переселиться со всем родом в Египет. В большинстве списков: «и ре ч $^{\text {іаковъ }}$

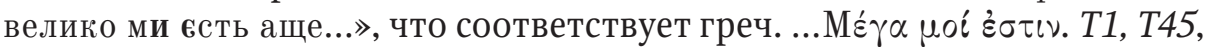
P1-подгруппа и Полная палея расширяют речь: «...велико ми добро е ${ }^{\mathrm{c}}$ » (Пг л. 118v, Сuн л. 133b) ${ }^{24}$. Имеется ряд аналогичных примеров ${ }^{25}$.

В некоторых случаях Полная палея следует за Троицкими Пятикнижиями, когда те предлагают близкие к исходным чтения. Покажу это на примерах трансформаций в именах. В Быт 14:1 T1, T45, Полная палея верно обозначают царя Элама, греч. Аì $\dot{\alpha} \mu:$ «лламескъ» (Пг л. 71v, Cuн л. 74d) - тогда как в Аpx, Варш, Вил здесь «салимескъ» / SO «еламерскыи» / RU «ламерескъ». В Быт 14:17 упоминается некая «оудоль», при этом ближе всего к греч. T45 и Пг: «са8и», ср. ню»; в основном списке T44 паримейная замена «савиноу», еще паримейные варианты T1 «савгиину» и $P 3$ «саввинъ»», остальные списки RU имеют «сена8є», что близко к Толковой палее «сънаоуи». К сожалению, близкие к Т45 чтения есть только в Пг л. 72r; Син л. 75с и Рм л. 56с иначе: «въ оудоли солищньмь».

Вместе с тем в палее обнаруживаются и существенные отклонения от ветви Троицких Пятикнижий. В 11 и T45 произведено множество паримейных замен там, где остальные списки сохраняют четий текст. В некоторых случаях Полная палея идет за большинством списков, а не за T1, T45. Напр., в Быт 22:2 Господь от Авраама потребовал принести в

\footnotetext{
${ }^{24}$ Кроме того, в приведенном чтении также и в SO попытка преодолеть лаконизм греческого текста: «велика мл ${ }^{\mathrm{c}} \mathbf{т ь}$ ми $\mathrm{e}^{\mathrm{c}}{ }^{\mathrm{s}}$.

25 Речь идет преимущественно об общих пропусках и изменениях форм. Напр., Быт 42:38 опущено слово в речи Иакова о Вениамине с отказом отпустить младшего сына в путешествие. В большинстве списков: (єда) «сА лоучить больти ємоу на поути . на нь же аще поидете» - чему в T1 и T45 соответствует: «оулучит сA / T45 л8чи ${ }^{\mathrm{T}} \mathrm{cA} /$ єму больти нан же аще поидеть»; Полная палея «ем8 сл8чить ${ }^{\mathrm{c}}$

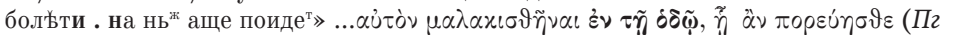
л. 112v, Син л. 126b). См. также Быт 43:7 «выпроси на ${ }^{c}$ моужь рода нашего» = T1, T45, П2, Син «о родъ нашемь» (Пг л. 112v, Син л. 126b). По Быт 43:23, «самчии» (болгаризм, 'домоустроитель') Иосифа отвечает приглашенным в дом его

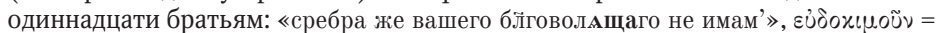
T1, T45, П2, Син «бл̈говоливаго» (Пг л. 113v, Син ош. бйоволивати л. 127d). Обнаружены также сближения с отдельными списками. Напр., с Т1 в Быт 28:17 «коль» Т1 Полная палея вм. «тако» (Пг л. 92r, Син л. 101a); Быт 41:47 Т1 Полная палея «обилныхъ» вм. «гобинны ${ }^{\mathrm{x}}$ (Пг л. 111r, Син л. 124b). Но таких примеров немного, и они спорны.
} 
жертву сына: «и възведи и тамо въ требоу на єдин8 ш̈ горъ» - T45 имеет паримейное «...и на шлкарфоє», 11 с порчей - перестановкой букв «и на

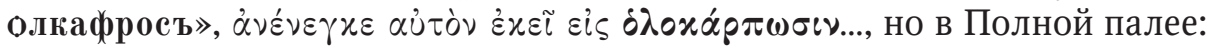
«въздаж ды ми требоу» (Пг л. 83r, Син л. 89c). Чуть ниже в Быт 22:5 Авраам собирается совершить жертвоприношение на горе и своим слугам

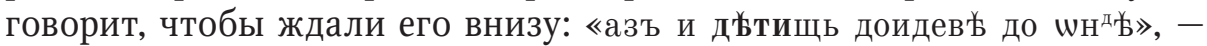
этому в T1, T45 соответствует паримейное «азъ же и отрочищь...», однако Полная палея соответствует большинству списков: «аз же и д'ьтищь» (Пг л. 83r, Син л. 89d «дьтище»).

Имеются и иные несоответствия версии Троицких Пятикнижий. Напр., в Быт 37:28 братья извлекли Иосифа из потока и «йдаша из-

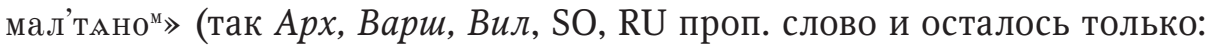
«шддаша»). В T1 и T45 здесь: «продаша изъмаилтомъ», однако Полная палея поддерживает большинство списков: «їдаша измаилитаншм (по Пг л. 102v и Рм л. 90b, Син л. 115b иначе: «даша измалтомъ»). В Быт 43:32 одновременно в RU и T1 содержится гаплографический пропуск: в стихе осталось лишь «и симь особь». По счастью, выражение сохранилось в Арx, Варш, Вил и, с небольшими изменениями, в SO: «и симь шсобь . [и бгиптАномъ . иже гдАхоу с нимъ шеобь]» ${ }^{26}$, что точно соотносится

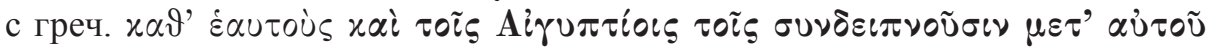

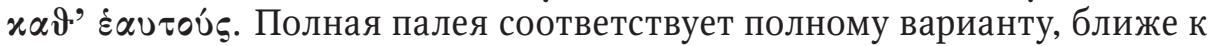
Иудейскому хронографу (Пг л. 114r, Син л. 128b).

Еще интереснее случай в Быт 44:27-28, где в RU имеется большой пропуск, см. ниже выражение в квадратных скобках, восстанавливаемое по тексту Apx, Варш, Вuл, SO. Иаков говорит своим оставшимся сыновьям о якобы утерянном Иосифе: «вы вьсте [гко два роди ми жена .

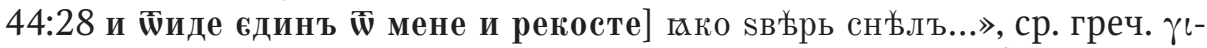

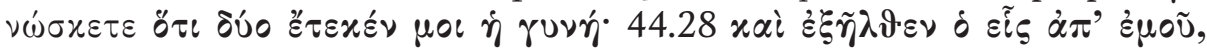

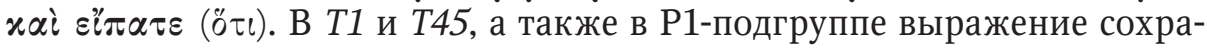
нено, но с дополнением, не имеющим соответствия в греч.: «...кко два сӥа роди ми...». Это распространение Полная палея не поддерживает. Следует добавить, что в палее небольшая ошибка: утерян слог «ди» в «роди» и переставлены слова, так что образовалось «рожена ми», ср.: «вы вьсте гкко два рожена ми . шииде единъ 灭 мене . и ркосте...» (так Пг

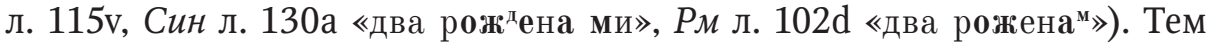
не менее ошибка происходит именно из первоначального чтения «дъва роди ми жена», без вставки слова «сына», каковая характерна для T1, Т45 и Р1-подгруппы.

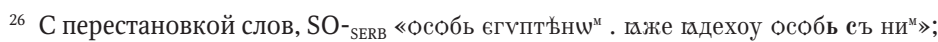
SO«...и егиПтаномь И гадах8 с нимь шсобь». 
В Быт 47:21 содержится редкое выражение «въ семиискоу», пере-

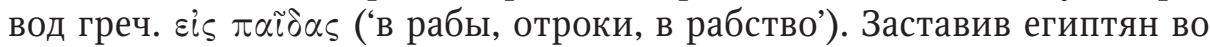
время голода заложить свою землю в обмен на пшеницу из хранилищ, Иосиф действовал на благо фараона. По Т44: «и люди поработи ємоу въ съм'ьискоу». Многие редакторы и переписчики не поняли смысл и решили во избежание сложностей вообще опустить темные слова. Сохраняется чтение в отдельных рукописях RU, а также Аpx, Варш: «в семииск $8 »^{27}$. T1, SO полный пропуск; в T45 и Р1-подгруппе усечено до: «всњ»; в одной из подгрупп RU-невR инновация: «и все мњсто»; еще в трех списках RU: «все имłніє искоупі». Полная палея также содержит данное выражение, хотя и с небольшой порчей. Составитель дописал слог, получив «всьми искоупы»: «и люди поработиша ${ }^{\mathrm{e}}$ ем8 всьвми иск8пы» (Пг л. 120d-r, Син л. 136b). Далее, см. Быт 48:19 речь Иакова о своих внуках Ефреме и Манассии: «и тъ б8деть въ люди [и сии възнесет са]», греч. xai oữ заключенное в скобки выражение, которое сохранилось у митрополита Илариона в «Слове о законе и благодати» ${ }^{28}$, в библейских сборниках по Аpx, Варш, Вил SO, а также Полной палее. При этом в T1, T45 вместе с Р1-подгруппой записано иначе: «и сии възвеселит сА», однако Полная палея инновации Троицких Пятикнижий здесь не отображает (Пг л. 121r, Син л. 137c).

В двух случаях Полная палея не тождественна Хронографической редакции в целом. См. Быт 47:28 о возрасте Иакова: «льътъ жизни єго», однако в списках Chr замена на «житиг», а Полная палея отражает вариант, общий для RU SO: «жизни его» (Пг л. 120d-r, Син л. 136c). Наконец, в Быт 49:31 верно воспроизведено имя старшей жены Иакова, Лии. Корректно текст здесь отражают SO и Полная палея, другие же списки воспроизводят местоимение «сію» (а $T 1$ «сего»): «...и ревекоу женоу єго

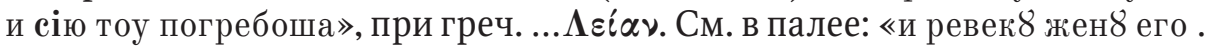
т8 погребоша лію» (Пг л. 126r, Син л. 143d).

Такая ситуация могла возникнуть, если, напр., в Полной палее производилась непоследовательная сверка по иным ветвям библейских книг. Надо сказать, когда сверка нерегулярна, ее сложно, а порою невозможно уловить, но какая-то активность редактора палеи в подобном направлении прослеживается. Обнаруживается даже сверка с греч., причем, похоже, компилятор обращался к оригиналу, нетвердо зная язык. Ср. поэтические речи Иакова о своем сыне Иосифе в предпоследней главе Бытия, где он завещает сыновьям заветы. Греческий

27 В Вил же переосмысление близко к Полной палее: всъми искоупи", см. ниже.

28 В цитате из четьего Бытия, правда, с пропуском слова «сии» («сь»), по списку 1-й редакции [Акентьев 2005: 128]. 
текст сложен, и в четьем переводе Восьмикнижия тоже не все нюансы оригинала переданы точно. В том варианте, который видим в Полной палее, видим попытки улучшить чтения, но и недопонятые фрагменты

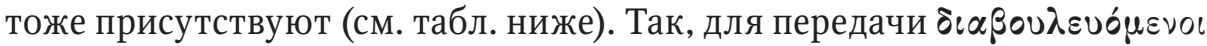
лучше старый вариант Восьмикнижия «сьвыщавающе», а не иннова-

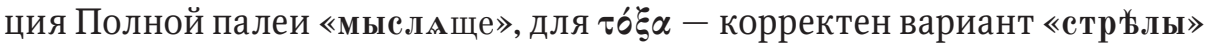
по Восьмикнижию, а не инновация «л8ци» ${ }^{29}$. Впрочем, палейное «гйе

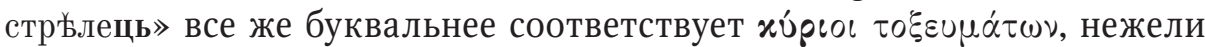

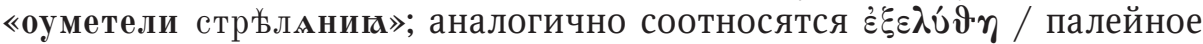

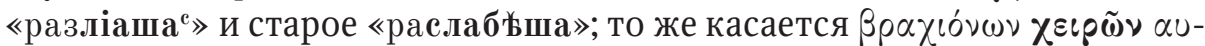
$\tau \tilde{\nu} \nu$ / палейное «мышцамь р8кь и ${ }^{\mathrm{x}}$ и и Восьмикнижие «мышца ихъ».

Таблица 3

\begin{tabular}{|c|c|c|}
\hline Пг л. $125 \mathrm{v}-126 \mathrm{r}$, Син л. $143 \mathrm{c}$ & T44 & [Septuaginta, 1: 464] \\
\hline 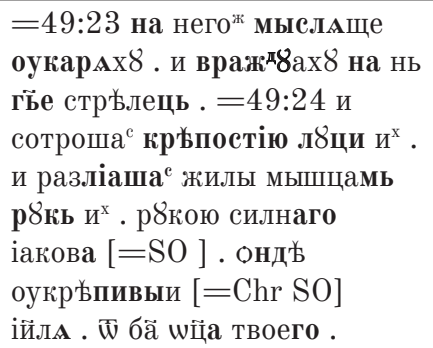 & 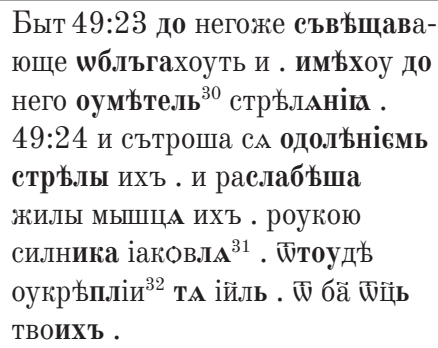 & 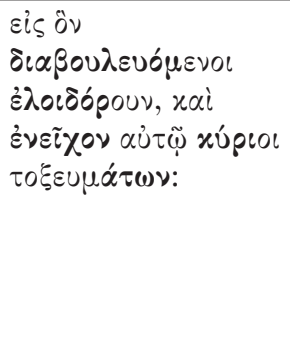 \\
\hline
\end{tabular}

Как видим, налицо усилия редактора улучшить перевод, причем в данном месте текст пророчества Иакова изменен значительно. Однако, в большинстве заимствований в Полную палею из четьего Бытия наблюдаем строгое соответствие четьему Восьмикнижию (иногда с паримейными включениями). Притом в палею скопировано немало, как уже отмечалось, приблизительно 1/4 объема из имеющихся пятидесяти глав Бытия. Конечно, в скопированные из Восьмикнижия отрывки составитель палеи вводил собственные инновации, четий текст переплетался с заимствованиями из Толковой палеи и сокращался, однако характерные чтения в десятках чтений прослеживаются достаточно однозначно. Поэтому длинный ряд совпадений с Троицкими Пятикнижиями, а также не такой длинный, но тем не менее впечатляющий ряд примеров,

\footnotetext{
29 В Масоретском тексте «лук», bow, имеется в виду оружие самого Иосифа, а не его неприятелей [Genesis 49:24]. Греч. здесь сильно отклоняется от МТ, аналогично совр. переводы.

30 Вил оумьетели; SO оум'̈телє.

31 T1, Т45 игаковлА; SO іакшва.

32 T1, T45, Вил SO Пг оукрьпивыи.
} 
когда Полная палея не соответствует отклонениям этой группы, нуждается в ином объяснении. Вероятно, редактор использовал ныне утерянный список, который восходил не непосредственно к группе Троицких Пятикнижий, а к более раннему этапу промежуточного общего протографа. Имеется в виду не общий с Иудейским хронографом протограф Хронографической редакции в целом, а протограф существующей группы Троицких Пятикнижий. Значимость наших наблюдений определяется двояко. С одной стороны, Полная палея поддерживает представленную всего лишь пятью списками Хронографическую редакцию, и ее данные расширяют возможности по сопоставлению текстов библейских сборников. С другой стороны - поскольку в Полной хронографической палее отражена одна из версий «Хронографа по великому изложению», связанного с древнерусским летописанием, характеристики палеи существенны также и в исследованиях хронографии и летописания. Сближения с Троицкими Пятикнижиями предоставляют косвенные данные о времени введения четьего текста в компиляцию.

\section{Список сокращений}

$\mathrm{Chr}$ - Хронографическая редакция Восьмикнижия

$\mathrm{RU}$ - Русская редакция,

RU-E ранняя группа Русской редакции;

RU-L поздняя группа

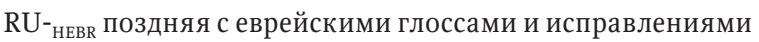

$\mathrm{SO}$ - Южнославянская редакция

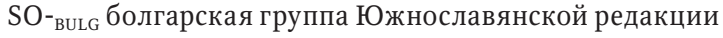

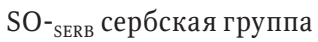

\section{Сокращенные названия библиотек и древлехранилищ}

ГИМ - Государственный исторический музей (Москва)

РГАДА - Российский государственный архив древних актов (Москва)

РГБ - Российская государственная библиотека (Москва)

РНБ - Российская национальная библиотека (Санкт-Петербург)

\section{Библиограсрия}

ИСТОЧНИКИ

Рукописи, сиглы рукописей

Apx

РГАДА, ф. 181, оп. 1, собр. МГАМИД, № 279/658, Архивский список Иудейского хронографа, III-я четв. XV в.

Bарш

Biblioteka Narodowa, Dział zbiorów specjalnych, BOZ, cim. 83, Варшавский список

Иудейского хронографа, 1-я пол. XVI в. 
Вил

Библиотека АН Литвы, F 19-109, Виленский список Иудейского хронографа, 1-я пол. XVI в.

$\Pi 2$

РНБ, ф. 588 собр. Погодина, № 1435, Погодинский список Полной хронографической палеи, 1-я треть XVI в.

P1

РГБ, ф. 256, собр. Румянцева № 27, Пятикнижие и др. статьи, к. XV - нач. XVI в.

$P_{\mathcal{M}}$

РГБ, ф. 256, собр. Румянцева № 453, Румянцева список Полной хронографической палеи, 1495 г.

$\mathrm{Cuн}$

ГИМ, собр. Синодальное № 210, Синодальный список Полной хронографической палеи, 1477 г.

T1

РГБ ф. 304. I, собр. Троице-Сергиевой Лавры № 1, Пятикнижие, к. XIV или нач. XV в., (Троицкий № 1 ).

T44

РГБ ф. 304. I, собр. Троице-Сергиевой Лавры № 44, Пятикнижие, к. XV в., (Троицкий № 44).

T45

РГБ ф. 304. I, собр. Троице-Сергиевой Лавры № 45, Пятикнижие, к. XVI в. (Троицкий № 45).

\section{Интернет-ресурсы}

Genesis 49:24

Genesis 49:24, Bible Hub: Online Bible Study Suite, 2004-216 (https://biblehub.com/ genesis/49-24.html).

\section{Литература}

Акентьев 2005

Акентьев К. К., «Слово о законе и благодати» Илариона Киевского. Древнейшая версия по списку ГИМ Син. 591, Истоки и последствия: Византийское наследие на Руси (= Византинороссика, 3), С.-Петербург, 2005, 116-152.

Алексеев 1993

Алексеев А. А., Русско-еврейские литературные связи до XV в., Jews and Slavs, 1, Jerusalem, St. Petersburg, 1993, 44-75.

Брандт 1894а

Брандт Р., Григоровичев паримийник в сличении с другими паримийниками, Чтения в Обществе истории и древностей Российских, 1, 1894, 1-89. 18946

Брандт Р., Григоровичев паримийник в сличении с другими паримийниками, Чтения 8 Обществе истории и древностей Российских, 3, 1894, 96-174. 1900

Брандт Р., Григоровичев паримийник в сличении с другими паримийниками, Чтения в Обществе истории и древностей Российских, 2, 1900, 184-182. 1901

Брандт Р., Григоровичев паримийник в сличении с другими паримийниками, Чтения 8 Обществе истории и древностей Российских, 3, 1901, 290-302. 
Вилкул 2015

Вилкул Т. Л., сост., Книга Исход. Древнеславянский полный (четий) текст по спискам XIV-XVI веков, Москва, 2015.

Вілкул, Ніколаєв 2020

Вілкул Т. Л., Ніколаєв С. Л., Книга Буття. Давньослов'янський четій текст за списками XIV-XVI століть (= Київське християнство, 22), вступ, упор. тексту Т. Л. Вілкул; покаж. слів С. Л. Ніколаєва, Львів, 2020.

Водолазкин 2007

Водолазкин Е. Г., Новое о палеях (некоторые итоги и перспективы изучения палейных текстов), Русская литература, 1, 2007, 3-23.

2009

Водолазкин Е. Г., Как создавалась Полная Хронографическая Палея, 1, Труды отдела древнерусской литературы, 60, С.-Петербург, 2009, 327-353.

Григоровичев Паримејник 1998.

Рибарова 3., Хауптова З., сост., Григоровичев Паримејник, Скопје, 1998.

Истрин 1907

Истрин В. М., Редакции Толковой палеи, С.-Петербург, 1907.

Михайлов 1900-1908

Михайлов А. В., Книга Бытия пророка Моисея в древнеславянском переводе, 1-4, Варшава, 1900-1908.

1912

Михайлов А. В., Опыт изучения текста Книги Бытия пророка Моисея в

древнеславянском переводе, 1: Паримейный текст, Варшава, 1912.

Палея Толковая 2002

Палея Толковая, под ред. Н. Л. Панкратова, А. М. Камчатнов, подготовка др. рус. текста и перевода на совр. рус. язык, В. В. Мильков et al., коммент., Москва, 2002.

Пичхадзе 1996

Пичхадзе А. А., К истории четьего текста славянского Восьмикнижия, Труды отдела древнерусской литературы, 49, С.-Петербург, 1996, 10-21.

Славова 2015

Славова Т., Историческата палея и славянска хронографска традиция, К. Дидди, ред.,

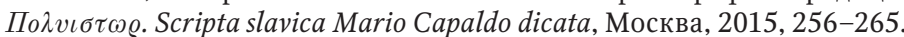
2018

Славова Т., Южнославянската ръкописна традиция на Книга Битие (археография, структура и сегментация на текста), Старобългарска литература, 57-58, 2018, 92-106.

Словарь книжников 1987

Словарь книжников и книжности Древней Руси, 1: ХI - первая половина ХIV вв., Ленинград, 1987.

Толковая палея 1892

Толковая палея 1477 года. Воспроизведение Синодальной рукописи № 210, 1, (= Общество любителей древнерусской письменности, 93), С.-Петербург, 1892.

Orlov 2009

Orlov A. A., Selected Bibliography on Transmission of Jewish Pseudepigrapha in Slavic Milieux, Selected Studies in the Slavonic Pseudepigrapha, Leiden, Boston, 2009, 299-306.

Reinhart 2007

Reinhart J., Die älteste Bezeugung der Historischen Paläa in slavischer Übersetzung (Cod. Slav. Vindob. nr. 158), Прилози за књижевност, језик, историју и фолклор, 73, Београд, 2007, $1-4,45-75$. 
Septuaginta 1974

Septuaginta. Vetus Testamentum Graecum, Auctoritate Academiae Scientiarum Gottingensis ed., 1: Genesis, J. W. Wevers, ed., Göttingen, 1974.

\section{References}

Akentiev C. C., "Slovo o zakone i blagodati" Ilariona Kievskogo. Drevneishaia versiia po spisku GIM Sin. 591, Idem, ed., Origins and outcomes: Byzantine heritage in Rus' (= Byzantinorossica, 3), St. Petersburg, 2005, 116-152.

Alexeev A. A., Russko-evreiskie literaturnye sviazi do XV v., Jews and Slavs, 1, Jerusalem, St. Petersburg, 1993, 44-75.

Orlov A. A., Selected Bibliography on Transmission of Jewish Pseudepigrapha in Slavic Milieux, Selected Studies in the Slavonic Pseudepigrapha, Leiden, Boston, 2009, 299-306.

Pichkhadze A. A., K istorii chet'ego teksta slavianskogo Vos'miknizhiia, Trudy Otdela drevnerusskoi literatury, 49, St. Petersburg, 1996, 10-21.

Reinhart J., Die älteste Bezeugung der Historischen Paläa in slavischer Übersetzung (Cod. Slav. Vindob. nr. 158), Prilozi za književnost, jezik, istoriju ifolklor, 73, Beograd, 2007, 1-4, 45-75.

Ribarova Z., Hauptová Z., eds., Paroimiarion Grigorovici, Skopje, 1998.
Slavova T., Istoricheskata paleia i slavianska khronografska traditsiia, C. Diddi, ed., Polyistōr. Scripta slavica Mario Capaldo dicata, Moscow, 2015, 256-265.

Slavova T., The South Slavonic Manuscript Tradition of the Book of Genesis: Archeography, Textual Structure and Segmentation, Medieval Bulgarian Literature, 57-58, 2018, 92-106.

Vilkul T. L., ed., Kniga Iskhod. Drevneslavianskii polnyi (chetii) tekst po spiskam XIV-XVI vekov, Moscow, 2015.

Vilkul T. L., Nikolaev S. L., The Old Slavic Book of Genesis after 14th -16th centuries manuscripts (= Kyivan Christianity Series, 22), Lviv, 2020.

Vodolazkin E. G., Novoe o paleiakh (nekotorye itogi i perspektivy izucheniia paleinykh tekstov), Russian Studies in Literature, 1, 2007, 3-23.

Vodolazkin E. G., Kak sozdavalas' Polnaia Khronograficheskaia Paleia, 1, Trudy Otdela drevnerusskoi literatury, 60, St. Petersburg, 2009, 327-353.

Wevers J. W., ed., Septuaginta. Vetus Testamentum Graecum, Auctoritate Academiae Scientiarum Gottingensis ed., 1: Genesis, Göttingen, 1974.

Тетяна Леонідівна Вілкул, доктор історичних наук,

провідний науковий співробітник Інституту історії України

НАН України

01001 Київ-1, Грушевського 4

Україна / Ukraine

tvilkul@gmail.com

Received December 3, 2019 